\title{
The Ormiston Philosophy: A Changing Education Paradigm
}

\author{
Luke Sumich
}

\begin{abstract}
Luke Sumich is one of the founders of Ormiston Junior College in Auckland, New Zealand. In this interview, he describes how the school came into being and the philosophy behind its personalized approach to education. He explains the views of the students and their parents as well as the challenges and hurdles encountered since the inception of the school. He concludes by offering advice for educators interested in innovative systems change.
\end{abstract}

It's apparent that you have established a wonderful new school in Auckland, New Zealand, called Ormiston Junior College. Can you tell us about the genesis of Ormiston?

The area that we have is sort of a sprawling suburb on the outskirts of Auckland that's now been encompassed by more sprawling suburbs. But the area was farmland and the government decided that they needed a strategy to get the seven schools built in this area. So, they made a break from tradition and sort of said, "What would be the best model for education in this area?" And they've gone for a primary school, which is our Year 1 to 6, and a junior college, which is our Year 7 to 10, and then I think one senior college, which is our Year 11 to 13. Traditionally in New Zealand, you could have had a full primary which went all the way to Year 8 and then a giant college that went from 9 to 13 . But they didn't want to have schools over a thousand students. They felt that at that point you start to lose a little bit of the intimacy of education. So, in the last eight years, they have been building these schools as the area has grown and the products have been developed in the housing. And we're the second-to-last piece of the puzzle, which is the junior college.

Evolving from that is what I would call a "perfect storm" — we're in a changing paradigm of education where we're moving away from content all the time. The school being a junior college is not a high school, but it's not a primary school. We picked up the funding from the government, so, we're funded as a high school and got a bit more money. And another beautiful thing is: we're not strangled by external countrywide exams because they only happen in senior college. We've got this perfect storm of a new build, brand-new facilities, excellent funding, and not getting hamstrung by external exams. All the stars have aligned for us to be able to come on and be reasonably creative and reasonably research-driven with education at the moment.

The vision as I understand it for Ormiston is to guarantee that every learner engages in innovative, personalized, and world-class learning. Can you describe what this looks like in terms of physical space, curriculum, pedagogy, and timetabling?

"Guarantee" was a very difficult word to include in our philosophy. But the point really is that, to go and chase that goal is a lofty goal, and to go and chase that goal we have to think about every learner and 
not consider the way things may have been ... children are doing very well in this way. Many schools are successful around the country and around the world and have a traditional style of teaching and learning and it's been wildly successful for lots of children. However, these often burnt pale. And so, when you talk about guaranteeing every learner, the words that came for us weren't "guaranteed"; it started to go to "every learner." And what we quickly realized is that there are a bunch of disengaged children who don't do well, who always seem to be failing ... the poor or the economically disadvantaged around the world and you will find that they're the ones that aren't engaged and, certainly, you couldn't guarantee that they would be getting the best. So, we needed to do "also/and." We have to be able to make sure that we still succeed with the ones that are succeeding in every school anyway. They have to guarantee that they're going to get over the line as well. Those that traditionally have struggled in a traditional education get across the line too.

So, what we really have done is have a look at the research and particularly research about what makes a successful learner or what makes a successful student or what makes a successful contributor to our country. And what it really comes back to: relationships are key to children's learning and there is a saying that, "children don't care how much you know until they know how much you care." And that couldn't be truer. We are working here with pre-teens and teens ... so the ages of our children are $12,13,14,15$. We also get the complexity of pubertal changes and, particularly, chemical changes in the brain at this time. Again, when I say "research," I'm talking also about the research around "relationships matter" and children who have a relationship with their teacher. But, also relationships on a level that allows us to understand the chemistry in the brain and understanding what's going on in the brain. And relationships also around: "I've made a mistake." Not "I'm telling you off" and blame. And we'll find with teenagers and with parents-parents will blame, and teenagers will react. We know in terms of a teenager that they will react rather than think logically. Taking the research to the actions, which is what I'm trying to do now is say: "We understand that teenagers ... the emotional part of their brain will kick in and the logical part of their brain will drop." And so, when you ask them, "What were you thinking?_-[they reply] "I don't know." "But why did you do that?" —"I don't know." If you ask them: "How do you feel about it? How do you feel about what's happened?" You'll go in and get an answer because they do have an emotional connection.

Now I moved it to action. So, what have we got? We see that each teacher in the school has a group of 12 to 14 students. They are known not as their teacher but as their "MAC," MAC meaning mentor, advisor, coach. These students need to have a MAC that they can rely on. If they enroll at the school in Year 7 at the age of 11 or 12, that MAC will be with them for the four years that they're here. The key to a lot of these relationships: build relationships; maintain them. Often, a teacher will have a relationship with a student, and then next year they get a different teacher and have to start all over again. So, why would we do that? And often a kid will behave well for six months for a teacher in a honeymoon period, [and say], "Oh she knows me, she knows me well, and she's talking to my parents." It almost becomes family and when you can get to family you can get to situations that will enable children to be in the best possible place for their learning because of the trust that's laid out in front of them. 
On a daily timetable, this teacher who has 12 to 14 kids, and their MAC, they will see ... in a week they will be with them four to four-and-a-half hours. They will be their academic coach. They will be their social and emotional advisor. They will be their mentor and advisor, and link with their parents. We have a lot of students that are not born in New Zealand or come from a second-language background, predominantly Asian, and the mentality of "being at the appropriate level" for a student like that is not appropriate for that family; "above" is the only place that students can be in terms of their learning for lots of our families. And this places massive pressure on our students. So again, to be able to have a person that understands education as an adult can almost act as "in loco parentis," which is sort of what you are as a teacher: you are a teacher and an adult at school and almost their parent for that period of time. On a daily action, we set up a timetable that allows us to build relationships and almost a "relationship curriculum."

There's also another thing around movement: children have to have some form of physical activity. Otherwise, they're delivered to school in a car, get out, sit around all day with their friends, get picked up, walk home, get fed, and repeat the process. Every child in our school will do a form of physical activity during the day. There's multiple choice from hip hop dance through to the walking group through to badminton and more, it's irrelevant really, what it is, but, for their mental health and well-being, every child, every day, will do some form of physical activity.

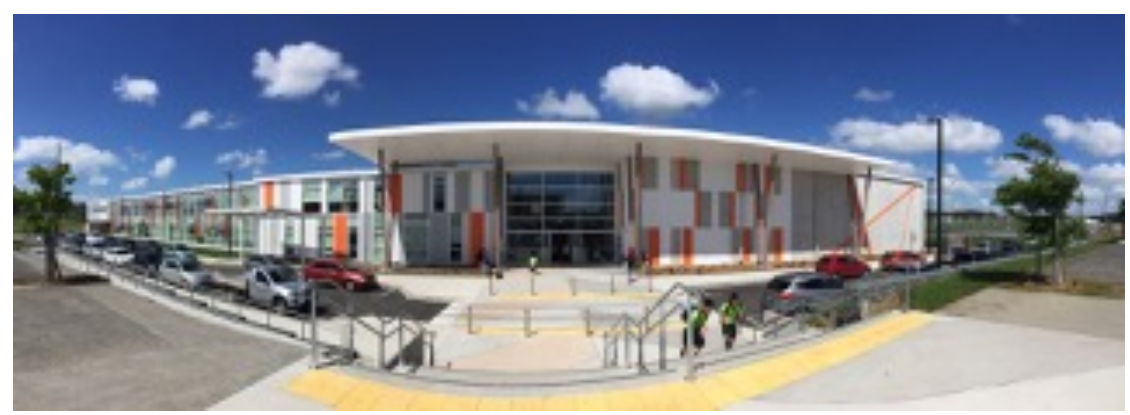

Fig. 1: Ormiston Junior College

Can you describe some of your innovative practices?

It's sometimes difficult for some people to consider "innovative" as being one thing and other people to just ... it can become a new norm. I suppose one of the things that I would think of as innovative: we took the New Zealand curriculum and we said, "What's the essence of the learning that is required?" There's detail as well in the New Zealand curriculum —-there's an essence and there's detail. If I just give an example in Science: the essence of Science ... generating and testing ideas, gathering evidence, making observations, carrying out investigations of the modeling, communicating and debating with others, in order to gain scientific knowledge. Those are really powerful essences. And if our kids could learn the essence of Science, that would be far more effective than when I switch to the back of the curriculum and I have a look at what it's saying in detail around Science and essences and astronomical science ... we should investigate the conditions of the Planet, of their moons, and the sectors affecting them. Now, that detail is lovely but not relevant. But generating and testing ideas, gathering evidence, making observations, carrying out discussions, are massively relevant. Those essence statements are very 
important. We wrote some criteria: "Can you give evidence children that you can generate and test ideas? Can you give evidence that you can make an insight and be able to prove that or disprove that? Can you debate and communicate with others?" That was essentially what we said was the most important thing to learn — not the planets. So, what we did with them was combine ... make it into a badge $\ldots$ and children had these badges and some of them are science-related, some of them are technology-related, some of them are science and tech. That badge that I just read there, that criteria ... that's almost every subject in the curriculum.

Children then go out and they do projects on whatever it is that they're chasing: some of them are doing global warming projects; some of them are looking at the old folks' home up the road and the impact on aged care; others have been working on fish ponds and looking at sustainable fishing and have actually traveled to Hawaii to look at the traditional Hawaiian coral fish ponds. But the point is that those areas of study that they go down: as long as they can work their way through the essence of the curriculum, then we feel that's far more valid and it's far more robust than us teaching a set of things like the planets. The Periodic Table is a great example: Why would I teach the Periodic Table? Why wouldn't I just be using it in some way?

We feel that that's reasonably innovative. But the real goal in this-I think this is the bit that's probably better thought through-is that we have then said to the children: "Ah, so at assessment time, how have you been going?" And what they have to do is come back and give evidence towards the criteria of that badge that says, "Here's what I've been doing." And they pitch back, they pitch back to their MAC - the 12-14 kids-and their teacher who's their mentor-advisor-coach, and they say, "This is the badge that I'm going for. Here's my evidence. Here's my learning." And they ask questions. And at the start, the kids ask questions, the teachers ask questions, and they grade and self-mark and grade for themselves.

I think that if we look at the key elements of the system: in a traditional school we might have had a test, marked that, and said, "You got a B minus." That feedback is horrid. There's no self-assessment, there's no peer assessment, there's no eliciting of evidence. They actually might have asked for an essay and used that as the evidence, and there's no shared learning expectation. If you really want to see full learning, I think that coming back and being able to talk about, describe, show and a test too, with your peers and your teachers ... I would call that probably quite innovative practice. That's one area that we could be very proud of.

Since the inception of Ormiston, what hurdles or challenges have you encountered?

The hurdles are traditional parental expectations. They went to school like all of us and they experience school like all of us that let's just go back to ... most of my parents would be born in the 70s or 80s, went to school in the early 80 s, early 90 s, late 80 s ... around that period of time. Their only knowledge of school is what happened to be. And now children have some choice in their education in what appears to be to them freedom or perhaps, "I don't like this new-fangled mucking around." So, it's an exercise in continuous upscaling of parents' knowledge of education, and some don't want to know: 
"My kid is at school ... can you just say nothing ... can you just give them a grade ... can they just pass?" With some that's quite difficult ... we do have some parents who want everything explained—not many-and they can be hard because they can be quite high maintenance and be not satisfied by something. And then you've got others that don't want to know, and then you've got others that are the silent majority - they're certainly happy because they think they're happy, but I'm not sure they really understand what and how we're trying to do things. We found getting them engaged in what we're doing $\ldots$ it would be much better if they were $100 \%$ behind us because they understood. There are many parents who are $100 \%$ behind us_-but it's not that they understand-it's just that their kids are happy. It's frustrating and it's a challenge. And I'm continually having to prove myself and the school and it's hard to live in that space every day.

What about the students? What do the students say about Ormiston?

There are some students that completely, enormously, and unequivocally have grabbed the whole concept and understand the whole concept, which I'm clapping and I'm so appreciative of those students. There are others that ... they go home, and their parents are saying, "What are you doing?" [And they answer], "I don't know." They feel a little pressure sitting in between their parents' opinions-which are not being voiced enough-and their own.

What are they saying? "They love it!" They absolutely love it and what is beautiful ... I got an e-mail the other day with attendance and this comes from the government and the government does assessment on attendance for every student in New Zealand. And they generalize you and they put your whole school in. You've got to understand: I've got year 7, 8, 9, and 10, and year 10, the year before all the exams start, and year 10 has the worst rate of attendance across New Zealand in terms of kids who wag or bump school or don't go or missed classes, or whatever. Our school in the ranking was out-of-control ahead of everybody in terms of attendance. We were 7 to 10 percent higher than private schools; we were above the schools that are similar community types-we were 15 percent ahead of them. There was a lovely little snapshot that arrived: we're doing something right from a real evidence base. The children really are getting a good ride-they love coming.

We had to develop together a set of values that we believed in as teachers and as a community. And when we push those values ... but one thing about teenagers, [they often say], "it's got to be fair," if it's not fair they don't want to know. And if we say: "We care about your personal health and wellbeing" - then we go and deliver there, and kids are seeing that. What I would say is the anecdotal evidence from parents is: "I can't believe this is the same kid that I had last year" (when they come to our school). So, we are here in terms of the children; they are our biggest advocates. And that's why they are a juxtaposition with the parents with their life's issue: "What's my biggest problem?" Also, they're our biggest advocates - that's why there's so many happy families because of the happy kids. 
What about the skeptics about academic success rates? How do you respond to that? How do your children fare?

We also do standardized testing across the country. If you sit on the spaces that we sit on, you can't afford to not be performing in all areas. I talked about also/and earlier on: the non-negotiable literacy and numeracy is non-negotiable literacy and numeracy! It is taught-it is rigorously taught. We're still running the standardized testing for reading, writing, and math to ensure that our numbers are holding up, improving, and getting better. And we've had some pretty outstanding results in terms of that. We're very comfortable that we can point fingers to that and be equal to and/or above our peers or with our peers in terms of our scope.

We get a lot of visitors-the neighboring schools, the schools around Auckland, a good 100-150 schools that walked through the doors this year. And my point to them is that we must share what we're doing with them and not belittle traditional education. There's a place for either/or, or there's a place for and/or, in our schools. So, I think the way to address setbacks is to embrace them as well and to let them know that some of the stuff that they're doing is completely valid and validated, and we haven't thrown that out as well. I think by doing that ... I ask people, I say to them when they come here: "Look, this is Version 1.1, and we're doing our best every day. And without the support of the education community, we're not going to make the little steps that everyone does. And if we're making giant steps for you what looks to be impossible, then clap and say thanks for opening a few doors because that's allowed us to take these smaller steps." I think setbacks are to be embraced-not to be pushed to the side and argued with. By doing that, we row the boat forward for education across the sector, rather than in one particular school.

If you were to give advice to other schools engaging in innovative systems change, what would you say?

It needs to be about "we," "we believe." You're not going to get the buy-in with saying: "This is going to happen; this is how it happens." I think that's really important that it does have to be about a "we," "we believe about learning." The second thing I would say is that surrounding yourself with people of more complementary skills, rather than similar skills. "Complementary" meaning almost "oppositional." $I^{\prime} m$ meaning it in a way that if I'm a creative thinker, and I fill the room with five creative thinkers, we're not going to get the job done. Some people have amazing ideas, thoughts, and processes, and they're required in the room. Also in the room is the detail person; they are required in the room. If the detail person is not there, action's not going to come from there. And the emotional thinkerthe EQ-is required in the room because with the EQ you can make great decisions and have great ideas, but you forgot there are people involved and this has an impact beyond where your thinking is going to take you. And then, of course, you've got to have the summative thinker-the person in the room that's got that "big picture" understanding. 


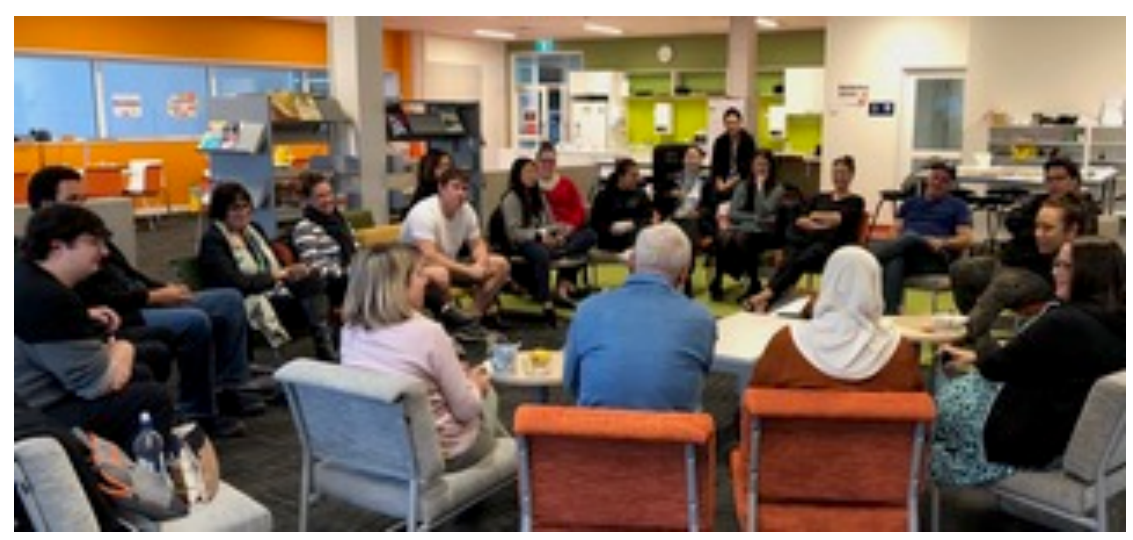

Fig. 2: Collaboration at work

I'm a real believer in having a diversity of thinking and a diversity of staff, a diversity of ideas, which, as long as the "we believe" are the norm, then you can really get leverage and get moving. You can't have a room full of diverse thinkers who aren't prepared to shift from what they believe/l believe/we believe-you won't get anywhere. I think that's the process that I sort of have ... that's what I've evolved over the last 30 years and 20 years of principalship and 30 years of teaching is that I've had to shift to other people's ideas that are better than mine. Therefore, what will I give up, what will I forego for the betterment of the team. There is a lovely word called "collaboration" that can mean many things. And [when it comes to] collaboration, people say often, "we'll share." But actually, collaboration is also about "giving away": I will hand away because in collaborative thinking and collaborative group thought, sometimes you've got to give stuff up. I'm a bit of a fan of having a diversity of thinkers and I'm a fan of setting a baseline_-and that baseline would be what we value and believe.

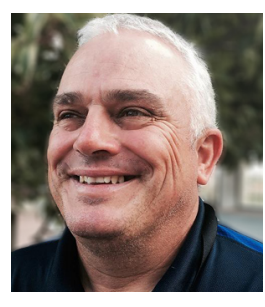

Luke Sumich loves test cricket, is a keen fisherman, handy golfer, and a long-suffering coach of every sport his children have chosen! He graduated from the Auckland College of Education in 1987. Luke has taught at Kedgley Intermediate, Onehunga High School. He was Principal at Punaruku School, foundation principal at Summerland Primary School, and is now foundation principal at Ormiston Junior College, Flatbush, Auckland. 